\title{
Documentation for students in residential care: Network of relations of human and non-human actants
}

Susanne Severinsson, $\mathrm{PhD}$ in Educational Practices, Assistant professor in Social Work Linköping University, Department of Social and Welfare Studies, Sweden.

Abstract: Swedish and international research points to serious problems for the education of students with social, emotional and behavioural difficulties (SEBD) in the care of social welfare, for example in residential care. The aim of this article is to elucidate how documentation, care plans (CPs) and individual educational plans (IEPs) outline the educational prospects for SEBD students in residential care. A more specific aim is to study how the form or template partakes in the production of educational trajectories. Using post-structural theory and the concepts of actor-network theory (ANT), this paper highlights the forms or templates as agentive forces in a network with students, parents, teachers and social workers. Documentation reveals few expectations that these teenagers can become capable learners and almost all of the subjects have been given a reduced curriculum. The lack of headings such as 'Student's or parents' opinion' or 'School subjects' can be understood as indications that these topics are considered to be of less importance. Individual differences between students disappear when the electronic document enables the use of the exact same phrases and words to describe different students. These results, along with previous research, point to an immediate need to discuss both the form and content of documentation in educational practice and to consider what, for what reason and for whom to document.

Keywords: individual educational plan; care plan; residential care; documentation; actor-network theory. 


\section{Introduction}

This article elucidate how documentation delineate educational prospects for students with social, emotional and behavioural difficulties (SEBD) in care of social welfare. According to several evaluations, the educational situation and future prospects for students diagnosed as having SEBD, have been shown to be most unsatisfactory, especially for students who are placed in residential care by social welfare authorities in Sweden, as well as and in many other countries (Berlin et al. 2011; Berridge et al. 2008; Daniels and Cole 2010; Landrum et al. 2003; Scherr 2007; Vinnerljung and Sallnäs 2008). U.S. research shows that students placed in residential care paradoxically are both over-represented and under-identified with respect to special educational needs (Zetlin 2006).

There are several reasons why the task to meet both educational and psychosocial needs is characterised by great complexity. The students do not always want to collaborate in these practices in the way in which they are invited to do (Berg 2010; Severinsson 2010; Severinsson and Markström 2015), and educational practices are created both for, and by the troubled youth. In addition, different actants such as teachers, social workers and parents consider these practices from different perspectives, sometimes in conflict with the teenagers involved. These educational practices also involve tensions between different social and educational needs, which must be negotiated and attended to. Finally, the forms and templates for educational and social needs and measures are also important for what is possible to formulate and enact. Despite these problems, every child has the right to attend school, even if he or she has been diagnosed as having SEBD. But how is it possible to combine the need for schooling with the need for care? How are problems understood and described within 
residential care, and what kind of education is planned for these students? To answer these questions, I have analysed documentation, care plans (CPs) and individual educational plans (IEPs) for SEBD students in residential care.

\section{Aim}

The aim of this article is to elucidate how documents, such as CPs and IEPs, outline the educational prospects for SEBD students in residential care. A more specific aim is to study how the form of the template partakes in the production of education trajectories. More specifically, I have investigated:

- What is documented, and what is focused on in the documentation, regarding care and education?

- How are the SEBD students' educational needs, social-problem needs, objectives and measures described in the documents?

- How are future prospects for education outlined?

\section{Previous research}

\section{School and residential care: A problematic field}

Both Nordic (Ferrer-Wreder et al. 2005; Vinnerljung and Sallnäs 2008) and international (U.S. and U.K.) studies show that in most cases, those who are placed as children in residential care by social services agencies have a considerably lower quality of life as adults. Sullivan et al. (2010) followed 159 American adolescents in foster care, and found that more than 8 school transfers take place over 6.6 years in care. Metaanalyses of 16 studies including 9950 students in foster care in US, Canada and France (Scherr 2007) about foster children's education evince an over-representation of 
students who are not qualified to move to a higher grade. This research indicates that exclusion from school is predictive of future exclusion from society. Daniels and Cole (2010), working in the United States, point out that the quality of education in these private special education settings is questionable, due to a lack of certified teachers; this problem is also seen in Sweden. Placement in a group home sometimes means that a student is simultaneously placed in an on-site private special education school with a more restricted programme than the student actually needs. Zetlin (2006) found that addressing the complex problems met by foster children and youth in the special education system is an urgent need.

In England, Berridge et al. (2008) point to the risk of isolation from mainstream education. They also see a relationship between educational success and care systems in which residential special schools for SEBD students have better educational achievements and work more to improve young people's self-esteem (as compared to English residential homes without their own schools). Landrum et al. (2003) conclude that students in the United States with emotional and behavioural problems have lower grades, fail more courses and have greater difficulties adjusting to an adult life. Similar structural problems are found in Europe. For example, Willman (2007) writes about 'forgotten' schools in a national survey, and shows that there are severe problems with the quality of special schools in Germany-where, for example, few special schools teach all subjects. Willman also claims, however, that there is a lack of research comparing inclusive education, which keeps SEBD students in ordinary classrooms, with special schools; so the question of whether an inclusive approach would benefit SEBD students' education still remains to be explored.

Landrum et al. (2003) study what is 'special' about special schools, and conclude that environmental cues are crucial for behaviour, and that best practice for 
SEBD students is impossible to create in an ordinary classroom. They argue for research-based technologies that focus on having the consequences of students' behaviour include both reinforcement and punishment. Cooper (2008) stresses the importance of creating a learning environment that meets emotional needs through a combination of standard classroom features and family-type nurture groups. Such environments would be created in ordinary schools, but would be outside mainstream classrooms; they would use good relationships to affect bad behaviour. In the United States, there is a debate about institutionalising foster care into orphanages in order to arrange both care and education in better ways (Daniels and Cole 2010). In Sweden, on the other hand, the responsibilities of ordinary schools are emphasised, and governmental discourse does not prefer the concept of creating institutions that include both education and care. Despite these intentions, placement outside of the mainstream classroom has increased for Swedish students in need of special education (National Agency for Education 2011).

In the United Kingdom, Zetlin (2006) and Berridge et al. (2008) study the question of why so many problems exist in arranging good schooling for students in foster care. They highlight the importance of increasing the cooperation between school and social workers to promote education for students in foster care. Berridge et al. (2008) state that social workers' emphasis on social and emotional factors rather than on educational matters creates a problem; and that carers' responsibilities for educational matters have been unclear. Severinsson et al. (2014) show that the dominant discourse 
in Swedish Homes for Care or Residency $\left(\mathrm{HVBs}^{1}\right)$ is that troubled youth must become more socially and emotionally stable before they can be properly educated. This 'discourse of care' legitimates the premise that students can wait until 'later' to go to school.

The schooling of students in the care of social welfare suffers from serious problems. Despite extensive efforts both in and out of home placement, students still drop out of school.

\section{Increased importance of documentation}

Why documents? The need for assessment and documentation of knowledge and learning can be seen as a phenomenon in a society where knowledge is primarily described as a factor for economic growth and competition (Rose et al. 2006). An example of this need is the current demand for reflexive individuals, which can be seen in plans to master the future, such as the Swedish state-regulated Individual Development Plans (IDPs) for all students in compulsory school. Another example can be seen in the requirement for IEPs when special difficulties arise. Previous research shows that, paradoxically, documentation often draws on discourses of what children 'have been' while simultaneously regulating how the students (and teachers and parents) draw on discourses of children as 'becoming', that is, children as objects of society's striving to construct good citizens (Alasuutari and Kelle 2015; Asp-Onsjö 2006).

\footnotetext{
${ }^{1}$ In Swedish, 'Hem för Vård eller Boende' or 'home for care and living'
} 
School documentation is expected to include written reviews on students' learning and to outline the measures required for students to achieve these goals. It should also provide guidance on what the teachers, school, student and parents can do to assist the student to achieve educational and social goals. All the actants are expected to influence and to be responsible for the documentation; for example, students influence what is written in the documents through their evaluations. Different actants contribute to the assessments and to constitutions of different positions as student, parent or teacher. This documentation obligation has increased for teachers in Sweden, as has the demand for students and parents to reflect on knowledge and achievements (Alasuutari and Kelle 2015; Markström 2015).

Moreover, the importance of involving students as well as parents in education is emphasised in the Swedish curriculum. For example, the curriculum stipulates that teachers conduct personal-development dialogues with every student in ordinary compulsory school, as well as with their parents/guardians, at least once per semester. During this dialogue, they discuss how the learning and social development of the student can best be supported, draw up and revise the IDP if needed, and establish an IEP if needed. Parents' roles in relation to the prevailing discourses on home/school relationships differ. For example, parents can be supposed to act as advocates for their children, or as consumers, partners and supporters. Parents can also be regarded as problems or learning entities (Hanafin and Lynch 2002). Asp-Onsjö (2006) shows how even in an 'ordinary' school, parents and students are generally informed about the measures in an IEP rather than regarded as real cooperators. Sometimes parents do not even know about their children having an IEP (Isaksson et al. 2007). When a student is segregated and placed outside the parents' home, the placement represents a kind of embedded disqualification of both parents and student (Hall et al. 2006; Roets et al. 
2015); it is interesting to investigate the enrollment of parents and students in this special situation.

Focusing on this kind of people-processing documentation tells us what society today wishes for its citizens, and what is seen as the proper action to take, if someone fails to reach the desired goals for a good citizen. Children are evaluated and may be considered as failing to reach the standard of the ideal citizen. Documentation creates a certain knowledge about possible life trajectories, and positions young people in certain ways (Alasuutari and Kelle 2015; Kelle et al. 2015).

\section{Method}

The empirical material consists of care plans (CPs) and individual educational plans (IEPs) about students, 13 to 15 years old, from two regions of Sweden who have been assigned to residential care. The documentation comes from HVBs, which are a special form of residential care, and their associated schools. This form of residential care, $80 \%$ of which is privately run, involves extended semi-professional foster care. In most cases, students at an HVB attend a public school in the vicinity; however, the empirical material in this article comes from HVBs that run their own schools and consequently are responsible for both care and education. Swedish HVBs with their own schools comprise not more than 32 out of all 800 HVBs. HVB with their own private schools, so called "free-schools", approved by Swedish School authorities, are a relatively new phenomenon in Sweden and therefore interesting to study. The school phenomenon of "free-schools" for SEBD students is increasing when ordinary schools in the same geographical area send their most "severe cases" to these special schools, although these students aren't residents at the HVB. Consequently, the most severe educational 
problems are thus handled outside the ordinary school. It is also possible to transfer students that ordinary schools find difficult to handle to these new kind of special schools were all students have behavioural problems.

The Swedish HVBs that use their own schools are categorised somewhere in between residential special schools and residential homes with schools. Although the youth lives at the HVB, it is common to visit parents for weekends and holidays if possible, and in that sense the setting is similar to a boarding school. The HVB can be seen both as a school where the youth lives, and as a home where the youth also goes to school.

Almost all students are identified as having SEBD, a categorisation filled with ambiguities (Winzer 2005) and that in itself is a social construct (Graham 2006). Young people categorised as having SEBD are placed at an HVB by Swedish social services, often voluntarily, but sometimes forcibly. The teenagers are commonly identified as aggressive and violent, committing crimes or acting self-destructively; in other words, they act 'mad, bad and sad' (Wright 2009, 288). Based on their emotional state and behaviour and also on their family situations, these young people are assessed by social services as being in need of intervention. They are placed in residential care institutions and special educational settings in the same way as are similar youth in many other countries (Landrum et al. 2003). These interventions are conducted within the framework of both educational and social services, and are thus situated in intersections between care, treatment and teaching. The interventions combine educational and therapeutic methods in a therapeutic milieu (Severinsson et al. 2014; Willman 2007).

Four out of six HVB-institutions with their own schools in the two regions of study agreed to participate. All students and parents were invited to participate and their consent decided the number, age, and gender of the participating students. All who 
agreed to participate was included in the study. The empirical material consists of IEPs and CPs for both girls and boys, including 17 CPs for nine boys and eight girls between 13-16 years old. Three of the girls do not have IEPs, so only 14 IEPs are covered in this study. The total number of pages is 164 . This article presents the results through examples that show typical findings in the empirical material as a whole.

\section{Theory}

These analyses are inspired by a post-structural theoretical framework, and combine actor-network theory (ANT) (Latour 2005) with the notion of assemblage outlined by Deleuze and Guattari (2004). This theoretical vantage point enables me to take several complexities into account, and to study special education documentation in residential care as a materialisation of a network of relations (Latour 2005) or as an assemblage (Deleuze and Guattari 2004) of thoughts, wishes and plans from different actants. Studies of assemblage show how knowledge and discourses from previous space-times create contingent and complex practices (McGregor 2004). ANT implies that power is a result of the mobilisation of resources in networks by the enrollment of human and nonhuman actants (Callon 1986; Latour 1986).

The documentation in this study can be seen as a stabilising, materialised actant and as a synthesis of norms and discourses (Alasuutari and Kelle 2015; Markström 2015). In the analysis, I regard the materiality of the documentation-both content and form - as an actant. I study the documents both as materialisations of networks of multiple social actants such as parents, teachers, principals and teenagers, and as nonhuman actants taking an active part in the process. Documentation does something to those whom it addresses. It suggests some interpretations and excludes others (Kelle et al. 2015). This view of documentation includes form as well as content; the form of the 
documents is an 'agentic force' (Alasuutari and Kelle 2015, 170) with headings, lines and boxes that stipulate some kinds of writing and exclude others.

Fenwick and Landri (2012) and Youdell (2006; 2011), who study the assemblages of education, inspired me to this type of analysis; however, I found my analytical tools in ANT (Callon 1986). Callon describes actants' interactions as translations between different human and non-human actants. Every translation process involves four characteristics, providing me with the following important analytical tools:

(1) Translations start with a problematisation where actants formulate the problems together.

(2) There are also interessement processes between different actants, which sometimes conflict; for example, between care and education or between students and teachers.

(3) The interessements lead to enrollments of the actants, in which they are assumed to act according to institutional assignments or assumed to resist their assignments. Actants can also be put aside as less important.

(4) Mobilisation does not always happen; however, in a successful translation, actions can spread and the solutions can be used in new networks (Callon 1986, 201-8).

\section{Ethical considerations}

There are several ethical concerns to consider in this project, since students in the care of social welfare are often in vulnerable situations. These documentation studies have 
been reviewed and accepted by the Swedish Central Ethical Review Board ${ }^{2}$. All HVBs involved, along with their actants, were anonymised; and youth, staff and parents gave their consent to participate and were informed of their right to end their participation at any time. The procedure followed by this study is described in detail in the decision of the ethical committee, such as the role of the HVB staff in collecting and anonymising documents and mediating contacts with students.

\section{Results}

First, I present an overview of my results to contextualise the rest of the findings. In the subsequent sections, I use two typical student examples of CPs and IEPs for my empirical material in order to elucidate how documentation outlines educational prospects for SEBD students in residential care and to explicate the importance of the form or template.

\section{Dominance of social problems and care discourse}

My analysis evinces that a discourse of care is dominant in both CPs and IEPs. In these documents eight of the 17 teenagers were diagnosed with ADHD. The diagnosis implies the prominence of a care discourse in combination with a medical discourse. Five of the eight diagnosed teenagers are boys. Based on neuropsychiatric diagnoses, five of the students are prescribed medicine (Concerta). Almost all of the ADHD-diagnosed

2 2013-02-07 (Dnr Ö 1-2013) 
teenagers also have an additional (neuro) psychiatric diagnosis, such as autism, Asperger's syndrome or depression. In addition, one girl is being examined for a putative ADHD-diagnosis, and another teenager is described as mentally disabled. Five of the teenagers have been abused, physically or sexually, by parents. One of the girls has sexually abused a mentally disabled adult male.

These diagnoses are used to account for why almost all the students have reduced curriculums and are studying few subjects. The individual explanations of the teenagers' problems are, for different reasons, almost all social-behaviour oriented; because of social insufficiencies, the students are interpreted as not being able to reach higher goals in school. Only one IEP includes descriptions of what the student has achieved in all school subjects. The standard IEP does not pay attention to what has already been achieved in school, and to what content remains in order to achieve the goal for each school subject grade. Rather, a typical IEP gives much information about problematic social behaviour and social problems but few solutions on how to reach school subject objectives.

\section{Individualised problematisation from discourse of social care}

In addition to an IEP, each of the teenagers also has a CP with room for social considerations and measures. These plans contain plentiful descriptions of social difficulties along with vague analyses that often end in comments on the need for 'structure and support'. The first example, which is representative for the empirical material, provides an excerpt from the beginning of an IEP regarding 'Alicia, 15 years old'. The form's spaces, both filled out and left empty, have been replicated in Excerpt 1.

\section{Excerpt 1:}




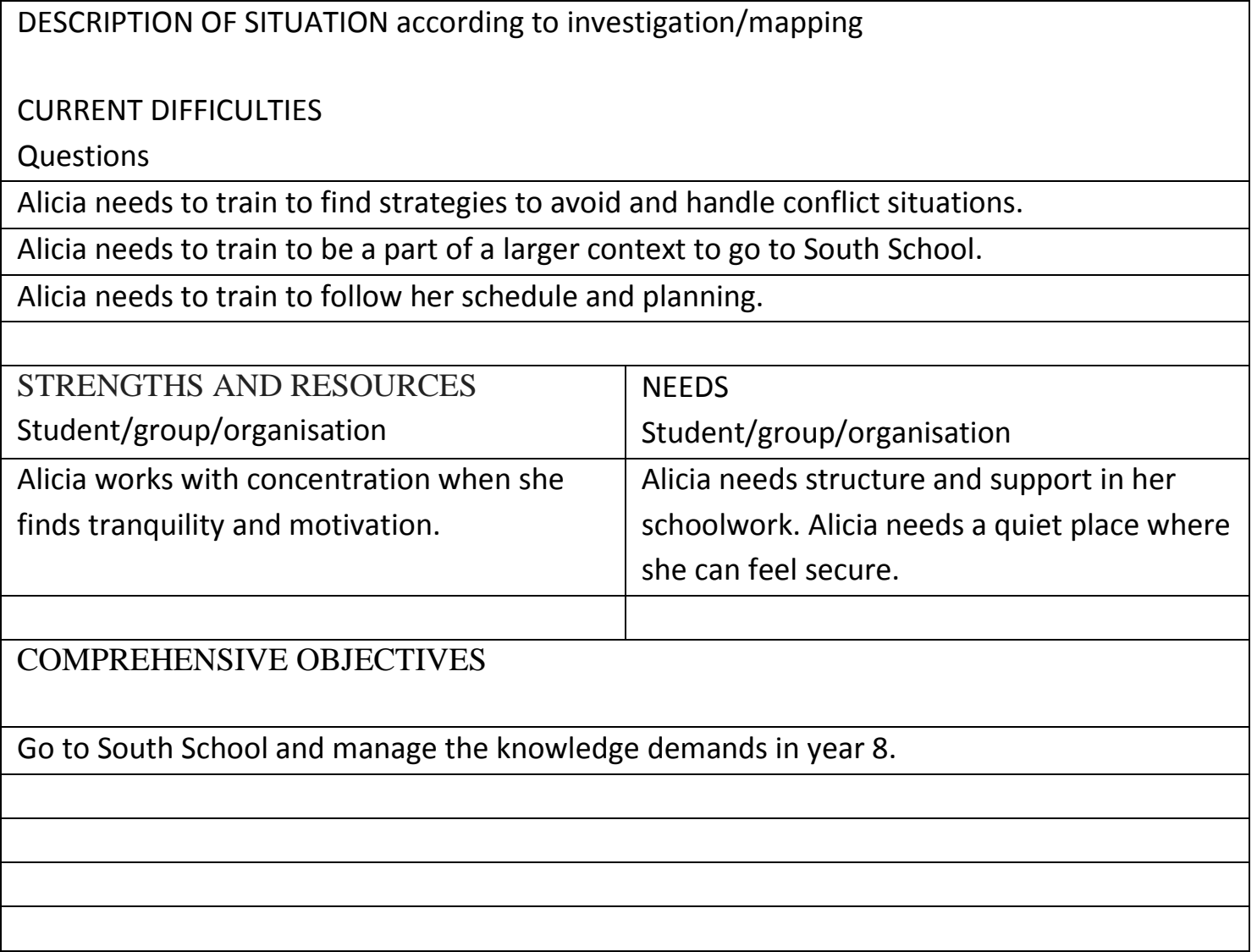

Despite being a school document, the content is mostly about social difficulties such as 'handling conflict situations' and 'being a part'. Different 'NEEDS' are described under that heading, but are also reiterated in the opposite column, 'STRENGTHS AND RESOURCES' as well in 'CURRENT DIFFICULTIES'. The form tries to divide its information between its three headings, and the interessement of the form is to clarify and sort, but the descriptions are blurred, and needs, strengths and difficulties are intertwined and similar. In addition, social and educational needs are enrolled as mixed together.

Each heading also has a subtitle, 'Student, group and organisation', and in that sense the form has an interessement of extending the interpretations of these difficulties beyond the individual level of Alicia. However, the form does not succeed in convincing the writer of these divisions. Neither problematisation of 'group and 
organisation' are specified, nor are any causes outside of Alicia herself. The solutions briefly connect to organisation when saying that 'Alicia needs a quiet place', but quickly return to Alicia as an individual in continuing 'so she can feel secure'. This lack of explanation outside of the individual can be seen as a disenrollment of other actants, such as the previous school, previous grades and relations with school, class and parents. Instead, the problematisation focuses on Alicia herself, and the needs are presented both as problems (e.g., 'Alicia needs to train...') and as a way of describing the efforts that are being made (e.g., 'Alicia needs structure and support'). Despite the form's interessement of division between individual, group and organisation, the problematisation follows the individual student. Alicia's own voice, and what she thinks about this explanation, is not clear; the form is more a text about the student than a text of the student. For example, Alicia's first name is used rather than the personal pronoun ' $\mathrm{I}$ '.

\section{Disenrollment of school subjects}

In the next section of the same IEP, the objectives are concretised and connected to different measures. This section is replicated in Excerpt 2. The 'part objectives' are mainly about 'attending' — first just one day, and later full-time — and a 'motivating talk' is the most common measure used.

Excerpt 2:

\begin{tabular}{|l|l|l|l|l|}
\hline Nr & Date & $\begin{array}{l}\text { Part objectives } \\
\text { Student/ } \\
\text { Group/organisation }\end{array}$ & $\begin{array}{l}\text { Measure } \\
\text { Approach/method }\end{array}$ & Responsible \\
\hline 1 & $20 / 1$ & $\begin{array}{l}\text { Attends one day a } \\
\text { week in South School }\end{array}$ & $\begin{array}{l}\text { Motivating talk. Cooperation with } \\
\text { South School to make Alicia be in } \\
\text { phase compared to class. }\end{array}$ & Rita Gina \\
\hline
\end{tabular}




\begin{tabular}{|l|l|l|l|l|}
\hline \multirow{2}{*}{} & $18 / 2$ & $\begin{array}{l}\text { Attends two days in } \\
\text { South School }\end{array}$ & $\begin{array}{l}\text { See above. And work through the } \\
\text { planning so Alicia follows her } \\
\text { schedule. }\end{array}$ & Rita Gina \\
\cline { 2 - 5 } & & & & \\
\hline 2 & $20 / 1$ & $\begin{array}{l}\text { Take part in all } \\
\text { common activities }\end{array}$ & $\begin{array}{l}\text { Motivating talk and prepare Alicia } \\
\text { for things to come. }\end{array}$ & Rita Gina \\
\cline { 2 - 5 } & & & & Rita Gina \\
\cline { 2 - 5 } & & & $\begin{array}{l}\text { Name of } \\
\text { Principal }\end{array}$ \\
\hline 3 & $20 / 1$ & $\begin{array}{l}\text { Comes to school every } \\
\text { day and feels that she } \\
\text { has good days at South } \\
\text { School }\end{array}$ & $\begin{array}{l}\text { Organisation cooperates around } \\
\text { Alicia to create good days. }\end{array}$ \\
\hline & & & & \\
\hline & & & & \\
\hline
\end{tabular}

The form tries to divide its discussion between objectives and measures, but the two are very similar. The measures could also be read as goals. They are enrolled very vaguely using wording such as 'work through', 'plan' and 'cooperate', and it is not clear how measures correspond to the objectives. This IEP must therefore also be difficult to evaluate in its progress towards achieved goals. Alicia enrolls as a girl with a short temper, who is easily disturbed and often absent. There is no description of Alicia's knowledge level in different school subjects, so the 'schoolgirl' Alicia is only vaguely enrolled. Despite her diminished school possibilities, the plan positions Alicia as someone who could manage quite high demands: It is a possibility that she could 'manage the knowledge demands in year 8' (which covers ages 14-15) as other teenagers without SEBD do. However, the plan at the same time enrolls Alicia as a 
student for whom it is enough if she 'attends one or two days'.

This form, along with the other actants in the network, produces a limited interessement of Alicia's possibilities to become a student. The objectives are vague, as they are in all the other plans, and do not explain how she might achieve the knowledge level for 'year 8'. If the IEP is seen as a network, it presents a disenrollment of schooloriented efforts such as school subjects, grades, exams and so forth. For example, the form does not preprint different school subjects such as 'Math', 'English' and so forth, in boxes for writers to fill in. Finally, I can see that the form's many empty lines have not been used; the form asks for more information than is given-another aspect that is also present in other plans.

\section{Unique but treated the same}

A deeper example of a CP involves Tessa, 15 years old (year 8), who is described as 'a talented person who performs well in school' and who 'has no problem in school thanks to the structure that exists around her today'. Tessa is described as not having attended school since the sixth grade; a few attempts at schooling were made at different schools, but with little success. Her situation is described as 'diagnosed with autistic traits and ADD, anxiety with school phobia and emotional disturbance, and for a long time she has had a child psychiatry therapeutic contact'. Similar descriptions are found in several of the CPs in the empirical material. Since Tessa was placed in an HVB in the spring of 2012, she has attended school every day. Many of the other plans in the study also refer to students attending school. Tessa's IEP from January 2013 is replicated in Excerpt 3.

\section{Excerpt 3:}




\section{Problem}

The student has no difficulties thanks to the structure around her.

Earlier, the student stopped going to school and stayed at home.

\section{Possible causes}

The school world becomes too big for the student to hold together, and then the student stops going to school.

\section{Need}

A clear structure that makes the student feel secure

\section{Objectives}

That the student thrives and comes to school every day

The introduction of this plan is very elementary, and formulated very briefly, even though the form's boxes are bigger than the text requires. The plan states that Tessa 'has no difficulties', despite her diagnosed issues. The problematisation here is not linked to school, but the problems are still connected to the individual and formulated as something that Tessa either has or has not. For example, the plan states that she 'has no difficulties'. The plan focuses on Tessa 'coming to school every day' but there are few descriptions of what is going to happen there. The plan's solution is that Tessa has 'structure around her', and this structure is linked to her managing school. The plan continues: 
Excerpt 4:

\begin{tabular}{|c|c|}
\hline Measures & Responsible \\
\hline $\begin{array}{l}\text { - Predominately one-on-one teaching. } \\
\text { This suits the student well; she also has group-teaching } \\
\text { with two school peers well-known to her. } \\
\text { - Separate classroom. } \\
\text { This suits the student well, and she works hard in her } \\
\text { room both with and without the teacher's aide. } \\
\text { - Monthly letter to parents. } \\
\text { Letter has been sent each month since school started. } \\
\text { - Access to psychologist, counsellor, doctor and school } \\
\text { nurse. } \\
\text { The student has regular contact with these persons. } \\
\text { Reduced curriculum and adjusted well-structured } \\
\text { schedule. } \\
\text { The student follows her schedule and manages the tasks } \\
\text { the teacher plans for the student. }\end{array}$ & $\begin{array}{l}\text { Mentor Hanna } \\
\text { Mentor Hanna } \\
\text { Principal Sophie }\end{array}$ \\
\hline
\end{tabular}

Tessa's IEP continues, with many more actions taken and different solutions noted despite the recorded fact that she 'has no difficulties'. Examples include plenty of outdoor teaching, adapted school material, interest-based materials and extra efforts for relation-building activities, such as sitting with the teacher during coffee break. Similar measures are present in many of the IEPs as a kind of standard procedure. The form's headings are written in bold type, and are in the standard format used for all students in this HVB. An evaluation of what the headings mean for a special student revealed more information. First, the digital form makes it easy to transfer text without showing that it is a standard text. It is impossible to see which text is standard and which is individually oriented, until you compare the plan with other plans from the same HVB. My analysis reveals not only similarities between headings, but also similarities between the formulations of measures for different students in several of the plans at the same HVB, with exactly the same words and phrases being used for different students. For example, 
the following sentence was used to describe all the students placed at the same HVB:

'to reach these objectives, $\mathrm{XX}$-institution offers time to cooperate and regular counselling about objectives and means, where the individual gets reflected guidance and feedback for their actions...'

With such repetition, the differences between students and the uniqueness of individual students fade away, and what is considered 'special' is revealed to be very similar from one student to the next. The borders between the form's agency (i.e., headings and prewritten text) and the text written by human actants for a specific student are blurred when the measures described for an individual student are exactly the same as those described for other students.

\section{Discussion}

Previous research shows that, regardless of intention, placement in special settings leads to a lack of education and to exclusion from school and society (Daniels and Cole 2010; Landrum et al. 2003; Scherr 2007; Zetlin 2006). Despite these findings, sometimes no solution is found other than segregation and placement in residential care, even though such placement affects the educational possibility of the student (Berridge et al. 2008). So what do institutional documents tell us about the school trajectories that are considered to be possible for these students, and how does the form or template partake in this process?

Together, the institutional actants determine what is made important, leading to the tensions and contradictions that are present within the institutional form and its written text. On one hand, the form tries to enforce explanations that are outside medical and psychological discourses. On the other hand, human actants ignore the 
form's headings about 'group and organisation' and provide mostly individual explanations. In other examples, the form and other actants agree, such as when historical discourse about schooling is absent, and when neither the form nor the writing mention supporters such as parents and previous teachers. The form has no space for students' or parents' own opinions. Nor are there any boxes or headings that provide interessement for highlighting the student's knowledge levels in each school subject.

The lack of educational discourse is legitimated by the use of medical discourse, and by diagnoses such as ADHD or Asperger's being described as the cause of the problems. Social and medical discourses dominate and documentation is focused on the individual, just as Isaksson et al. (2007) found in ordinary school. The enrollment of these individual-focused difficulties, connected to the dominant discourse of care, legitimates lowering the requirements that these teenagers must achieve in school. Consequently, these teenagers are not enrolled as competent students; their plans do not even note what they achieve or fail to achieve in school subjects. The interessement of educational discourse appears to be less important in these documents than one might expect. The IEPs do not focus on school subjects, except at one of the schools, and the most important goal for students is to 'be' in school, rather than striving towards goals at school. Objectives are often vague and the analyses are quite short. An IEP cannot serve as a guide for the student or for teachers, due to its abstract and social-oriented form. The same scenarios are repeatedly described in many of the IEPs, sometimes using exactly the same words even in content that is supposed to describe a unique situation.

Could the documentation be translated to mean that school is not seen as important? Or, is such an interpretation impossible to claim in this situation-that is, 
could school still be seen as important even if that importance is not reflected here? As mentioned earlier, Landrum et al. (2003) conclude that best practice for SEBD is impossible to create in an ordinary classroom. My study seems to indicate that it is no easier to arrange education outside of the ordinary classroom than within it, because students are enrolled as being almost incapable of receiving teaching due to their social difficulties. Cooper (2008) stresses the importance of creating a learning environment that meets emotional needs through a combination of standard classroom features and nurturing groups. He calls this kind of environment 'pastoral care'. The cases in this study are surely examples of pastoral care, but the teenagers receive a reduced curriculum anyway. This is part of the 'circle of exclusion' (Razer et al. 2013, 1156), in which students are alienated from education despite their educators' good intentions. This result is an example of how discourses and explanations used in the classroom do not produce inclusion without its otherness, exclusion, as discussed by Hansen Hedegaard (2012). Despite already being segregated in a special setting, the students studied in this article are excluded once more.

Wright (2009) highlights the importance of shared perspectives and discourses beyond the usual professional ones (i.e., from teachers, counsellors and social and health workers) to provide both good care and good education for troubled youth. These plans are not examples of Wright's recommendations. Sometimes it is difficult to understand for whom the IEPs are actually written. These IEPs could better function as reports to social services or proofs of goodwill to parents, rather than as actual plans for students and their educators and caregivers to follow.

My results are in some aspects similar to the results from studies on documentation in ordinary schools. Institutional actants' documentation seems to feature the same interessements and enrolments, regardless of whether they take place 
in segregated practices or not (Andreasson et al. 2013; Isaksson et al. 2007). Parents and students are, also in my study, very little enrolled in such documents. Categorisations are individual-focused with little attention paid to organisational or structural issues, just as they are in ordinary school. Because of the individual explanations there is neither need for schools nor teachers to be evaluated.

\section{Conclusion}

Using the post-structural theoretical framework of ANT (Callon 1986; Latour 2005), I have highlighted the powerful agency of the forms and templates (Alasuutari and Kelle 2015; Kelle et.al 2015) and how it outline the educational prospects for SEBD students in residential care. The documentation covered contains few expectations that the teenagers can become capable learners; almost all teenagers have been given a reduced curriculum that will considerably complicate further studies. The documents are oriented around individual social shortcomings. The lack of headings such as 'School subjects', 'Parents' and student's opinion' or 'School history' indicates that these topics are considered to be of less importance. With the exception of one school, the IEPs have no spaces provided for students' school subject knowledge, school-related levels and abilities, what the parents and student think, and text about school experiences. The results also show how individual differences between students disappear when the electronic documents enable the use of the exact same phrases and words to describe different students' situations.

These results, along with previous research, show an urgent need to discuss both the form and the content of documentation in educational practice and to consider what, for what reason and for whom to document. The significance of documentation must be 
better interrelated to, and become a basis for, improvement of educational practices and not be used to position individuals as impossible learners. 


\section{References}

Alasuutari, M., and H. Kelle. 2015. "Documentation in Childhood." Children \& Society 29: 169-73.

Andreasson, I., L. Asp-Onsjö, and J. Isaksson. 2013. "Lessons Learned from Research on Individual Educational Plans in Sweden: Obstacles, Opportunities and Future Challenge." European Journal of Special Needs Education 28 (4): 413-26.

Asp-Onsjö, L. 2006. Åtgärdsprogram-dokument eller verktyg? En fallstudie i en kommun [Individual Education Plan-Document or Tool?]. Göteborgs University.

Berg, K. 2010. "Negotiating Identity: Conflicts between the Agency of the Pupils and the Official Diagnosis of Social Worker and Teachers." European Educational Research Journal 9 (20): 164-76.

Berlin, M., B. Vinnerljung, and A. Hjern. 2011. "School Performance in Primary School and Psychosocial Problems in Young Adulthood among Care Leavers from Long Term Foster Care." Children and Youth Services Review 33: 2489-97.

Berridge, D., C. Dance, J. Beecham, and S. Field. 2008. Educating Difficult Adolescents. Effective Education for Children in Public Care or with Emotional and Behavioural Difficulties London: Jessica Kingsley Publishers.

Callon, M. 1986. "Some Elements of a Sociology of Translation: Domestication of the Scallops and the Fishermen of St Breuc Bay." In Power, Action and Belief. A New Sociology of Knowledge," ed. Law, J. 196-233. London: Routledge \& Kegan Paul.

Cooper, P. 2008. "Nurturing Attachment to School: Contemporary Perspectives on Social, Emotional and Behavioural Difficulties." Pastoral Care in Education 1, (13): 13-22.

Daniels, H., and T. Cole. 2010. "Exclusion from School: Short-Term Setback or a Long Term of Difficulties?" European Journal of Special Needs Education 25 (2): 115-30.

Deleuze, G., and F. Guattari. 2004. A Thousand Plateaus: Capitalism and Schizophrenia. London: Continuum.

Fenwick, T., and P. Landri. 2012. "Materialities, Textures and Pedagogies: SocioMaterial Assemblages in Education." Pedagogy, Culture and Society 20 (1): 17.

Ferrer-Wreder, L., H. Satin, C. Cass Lorente, J.G. Tubma, and L. Adamson. 2005. Framgångsrika preventionsprogram för barn och unga. En forskningsöversikt [Successful Prevention Programs for Children and Young People. A Research Review]. Stockholm: Gothia.

Graham, L. J. 2006. "Caught in the Net: A Foucaultian Interrogation of the Incidental Effects of Limited Notions of 'Inclusion'." International Journal of Inclusive Education 10 (1): 3-24.

Hall, C., S. Slembrouck, and S. Sarangi. 2006. Language Practices in Social Work. Categorisation and Accountability in Child Welfare. London: Routledge. 
Hanafin, J., and A. Lynch. 2002. "Peripheral Voices: Parental Voices, Social Class and Educational Disadvantage." British Journal of Sociology of Education 23 (1): $35-49$.

Hansen Hedegaard, J. 2012. "Limits to Inclusion." International Journal of Inclusive Education 16 (1): 89-98.

Isaksson, J., R. Lindqvist, and E. Bergström. 2007. "School Problems or Individual Shortcomings? A Study of Individual Educational Plans in Sweden." European Journal of Special Needs Education 22 (1): 75-91.

Kelle, H., R. Seehaust, and S. Bollig. 2015. "Child Health Records as Socio-Material Instrument of Distributing Responsibility. A Comparative Analysis of Paediatric Documents from Austria, England and Germany." Children \& Society 29: 184197.

Landrum, T., J. M. Tankersley, and J. M. Kauffman. 2003. "What Is Special about Special Education for Pupils with Emotional and Behavioural Disorders?" The Journal of Special Education 37 (3): 148-56.

Latour, B. 1986. "The Powers of Associations." In Power, Action, Belief. A New Sociology of Knowledge, ed. Law, J. London: Routledge \& Kegan Paul.

Latour, B. 2005. Reassembling the Social: An Introduction to Actor-Network-Theory. Oxford: University Press.

Markström, A.-M. 2015. "Children's Views on Documentation in Relations between Home and School." Children \& Society 29: 231-41.

Mcgregor, J. 2004. "Spatiality and the Place of the Material in Schools." Pedagogy, Culture \& Society 12 (3): 347-72.

National Agency for Education. 2011. "Särskilt stöd i grundskolan. En sammanställning av senare års forskning och utvärdering [Special support in compulsory school. A compilation of research and evaluation from the past few years]." Skolverkets rapport 2008: 1033, revised 2011.

Razer, M., Friedman, V. J., and B. Warshofsky. 2013. "School as Agents of Social Exclusion and Inclusion." International Journal of Inclusive Education 17 (11): $1152-70$.

Roets, G., K. Rutten, R. Roose, C. Vandekinderen, and R. Soetaert. 2015. "Constructing the 'Child at Risk' in Social Work Reports: A Way of Seeing Is a Way of Not Seeing." Children \& Society 29: 198-208.

Rose, N., O'Malley, P., and Valverde, M. "Governmentality." Annual Review of Law and Social Science 2: 83-104.

Scherr, T. G. 2007. "Educational Experiences of Children in Foster Care: MetaAnalyses of Special Education, Retention and Discipline Rates." School Psychology International 28: 419-36.

Severinsson, S. 2010. Unga i normalitetens gränsland: Undervisning och behandling $i$ särskilda undervisningsgrupper och hem för vård eller boende [Adolescents in the Borderland of Normality: Education and Treatment in Special Education Classes and Foster Institutions]. Vol. PhD in Social and Welfare Studies. Linkoping, Sweden: Linkoping University. 
Severinsson, S., and A.-M. Markström. 2015. "Resistance as a Means of Creating Accountability in Child Welfare Institutions." Child \& Family Social Work 20 (1): $1-9$.

Severinsson, S., C. Nordh, and E. Reimers. 2014. "Ambiguous Spaces for Troubled Youth. Home, Therapeutic Institution or School?" Pedagogy, Culture and Society 23 (2): 245-64.

Sullivan, M., L. Jones, and S. Mathiesen. 2010. "School Change, Academic Progress, and Behavior Problems in a Sample of Foster Youth." Children and Youth Services Review 32 (2): 164-70.

Vinnerljung, B., and M. Sallnäs. 2008. "Into Adulthood: A Follow-Up Study of 718 Young People Who Were Placed in Out-of-Home Care During their Teens." Child and Family Social Work Journal 13 (2): 144-55.

Willman, M. 2007. "The Forgotten Schools. Current Status of Special Schools for Pupils with Social, Emotional and Behavioural Difficulties in Germany: A Complete National Survey." Emotional and Behavioural Difficulties 12 (4): 299-318.

Winzer, M. 2005. "International Comparisons in EBD." In Handbook of Emotional and Behavioural Difficulties, eds Clough, P, Garner, P, Pardeck, JT, and Yuen, F. London: Sage Publications Ltd.

Wright, A.-M. 2009. "Every Child Matters: Discourses of Challenging Behaviour." Pastoral Care in Education 27 (4): 279-90.

Youdell, D. 2006. Impossible Bodies, Impossible Selves: Exclusions and Pupil Subjectivities. Dordrecht: Springer.

Youdell, D. 2011. School Trouble: Identity, Power and Politics in Education. Abingdon: Routledge.

Zetlin. 2006. "The Experiences of Foster Children and Youth in Special Education." Journal of Intellectual and Developmental Disability 31 (3): 161-65. 